\title{
Occurrence of linezolid induced thrombocytopenia and its association with the risk factors: a review article
}

\author{
Radha A. ${ }^{1 *}$, Anuradha H. V. ${ }^{1}$, Radhika K. ${ }^{2}$
}

${ }^{1}$ Department of Pharmacology, ${ }^{2}$ Department of Community Medicine, M.S. Ramaiah Medical College, Bangalore, Karnataka, India

Received: 05 October 2018

Revised: 25 October 2018

Accepted: 29 October 2018

*Correspondence to:

Dr. Radha A.,

Email: puttebun@gmail.com

Copyright: () the author(s), publisher and licensee Medip Academy. This is an openaccess article distributed under the terms of the Creative Commons Attribution NonCommercial License, which permits unrestricted noncommercial use, distribution, and reproduction in any medium, provided the original work is properly cited.

\begin{abstract}
Linezolid is the oxazolidinone group of antibiotic with wide range of activity against the gram positive bacteria including methicillin resistant staphylococcus aureus and penicillin resistant pneumococci and vancomycin resistant enterococci. Patients who are on linezolid were reported to have reversible myelosuppression especially thrombocytopenia and anaemia. Since there are less number of studies regarding the occurrence of thrombocytopenia and the risk factors associated with it, this study was undertaken to evaluate the occurrence of linezolid induced thrombocytopenia and its association with risk factors. It was a systematic review with synthesis of available literature in English language. Articles were retrieved using search terms included "linezolid", "and", "or", "thrombocytopenia" from Clinical key and PubMed, published during 2000 2017. Out of 16 studies retrieved, only 7 studies were analysed based on inclusion and exclusion criteria; of them, 3 were found to be prospective and retrospective cohort each and only one was retrospective cross-sectional study. The occurrence of linezolid induced thrombocytopenia range from $18-50 \%$ with normal renal function and $57 \%$ of incidence associated with renal insufficiency patients. The risk factors were found to be dose of linezolid $>18-27 \mathrm{mg} / \mathrm{kg}$, body weight of subjects $<55 \mathrm{~kg}$, creatinine clearance $<88.39$ to $60 \mathrm{ml} / \mathrm{min} / 1.73 \mathrm{~m}^{2}$ and baseline platelet count $<200 * 103 / \mathrm{mm}^{3}$, serum albumin concentration, serum creatinine, concomitant caspofungin therapy and duration of linezolid therapy.
\end{abstract}

Keywords: Baseline platelet count, Linezolid, Occurrence, Oxazolidinone, Risk factors, Thrombocytopenia

\section{INTRODUCTION}

Linezolid is the Oxazolidinone group of antibacterial agent with wide range of activity against the gram positive bacteria including Methicillin Resistant Staphylococcus Aureus (MRSA) and penicillin resistant pneumococci and vancomycin resistant enterococci. ${ }^{1}$ It disrupts bacterial growth by inhibiting the initiation process of protein synthesis by binding to domain $\mathrm{V}$ of the $23 \mathrm{~S}$ ribosomal RNA of the 50S subunit of bacterial ribosomes., ${ }^{2,3}$ Linezolid site of inhibition occurs earlier in the initiation process than other protein synthesis inhibitors like chloramphenicol, clindamycin, aminoglycosides and macrolides that interfere with the elongation process. ${ }^{4}$ The site of inhibition is specific to linezolid, so cross-resistance to other protein synthesis inhibitors has not yet been reported. It may also suppress virulence factor expression and decrease toxin production in gram-positive pathogens. ${ }^{5}$ It has $100 \%$ bioavailability by oral because it has high water solubility and robust tissue penetration. ${ }^{6}$ It is metabolized by liver into two primary oxidation products and $80 \%$ of the drug was excreted through kidney and $20 \%$ in the feces respectively. ${ }^{7,8}$ It's half-life 
approximates 5-7 hrs and the dosing interval is $12 \mathrm{hrs}^{9}$ Patients who are on treatment with linezolid were reported to have reversible myelosuppression, especially thrombocytopenia and anaemia. Thrombocytopenia has the highest incidence of $30 \%$ and anaemia with $2.8-47.3 \%$ among patients receiving linezolid. ${ }^{10}$ The risk factors for linezolid treatment are thrombocytopenia, renal insufficiency, chronic liver disease, respiratory tract infection, duration of linezolid therapy, baseline platelet count, low body weight and the use of vancomycin. ${ }^{11}$ Hence, patients should be observed for myelosuppression during linezolid treatment because it can occasionally result in discontinuing the treatment. ${ }^{12}$ As there were limited studies in this regard, we sought to review and evaluate the occurrence of linezolid induced thrombocytopenia and the associated risk factors.

\section{REVIEW OF LITERATURE}

\section{Search strategy}

Authors carried out a systematic review with synthesis of available literature in English language. Articles were retrieved using search terms included "linezolid", "and", "or" "thrombocytopenia" from Clinical key and PubMed published from 2000 to 2017 . Out of 16 studies retrieved, only 7 studies were analysed based on inclusion and exclusion criteria; of which 3 each were prospective and retrospective cohort and only one was retrospective cross sectional study.

\section{Inclusion criteria}

Authors have been included the studies in which patients aged $\geq 18$ years and on linezolid therapy more than 3 days.

\section{Exclusion criteria}

Studies included patients who had severe thrombocytopenia $\left(<50 * 10^{9} / \mathrm{L}\right)$ before linezolid treatment, bleeding disorder, known liver disease, coagulopathies, on any anticancer drugs during linezolid therapy, platelet count not recorded before or after linezolid therapy, suffering from cancer, missed clinical data and case reports were excluded.

\section{Data extraction}

Authors discarded irrelevant studies after screening all titles and abstracts and evaluated the full texts of the remaining studies to determine the inclusion and exclusion criteria.

The entire selection process is summarized in the PRISMA flow chart (Figure 1). Demographic, epidemiological, clinical variables were collected in detail including epidemiological design of the study, location of the study, age of the enrolled patients, dose and duration of the drug, baseline platelet count, creatinine clearance, the risk factors associated with thrombocytopenia and occurrence of thrombocytopenia.



Figure 1: Study flow chart.

\section{DISCUSSION}

Out of total seven articles reviewed; four studies were performed in Japan, two in China, one each in Taiwan and Italy. Thrombocytopenia definition used varied among the studies; thrombocytopenia is considered, if there was $>25 \%$ reduction from the baseline platelet count with final platelet count $<1 \mathrm{lakh} / \mathrm{mm}^{3},>25 \%$ reduction from the baseline platelet count only; $>30 \%$ from the baseline platelet count; ${ }^{7}>50 \%$ from the baseline platelet count (Table 1)..$^{1,6,11,13-15}$

Two studies which defined thrombocytopenia as $>25 \%$ reduction from the baseline platelet count and final platelet count $<1 \mathrm{lakh} / \mathrm{mm}^{3}$ has shown the occurrence ranging from $18-48 \%$ with mean age range of 66 to 83 years with mean dose of $24 \mathrm{mg} / \mathrm{kg}$ in one study and $600 \mathrm{mg}$ BD in other study and mean duration of 12 to 14 days. ${ }^{1,13}$ Another two studies with thrombocytopenia definition $>25 \%$ reduction from the baseline platelet count showed the occurrence of about $16.6-50 \%$ with mean age of 50-61 years with a mean dose of $17-20 \mathrm{mg} / \mathrm{kg}$ in one study and $600 \mathrm{mg}$ BD in another study for mean duration of 8 days -12 weeks. ${ }^{11,15}$

Study with definition of thrombocytopenia $>30 \%$ from the baseline platelet count showed occurrence of $48.4 \%$ with mean age range of 61-67 years with mean dose of $21 \mathrm{mg} / \mathrm{kg}$ with mean duration of 11-16 days. ${ }^{7}$

Study which has considered thrombocytopenia $>50 \%$ from the baseline platelet count in another study, had an occurrence of $48 \%$ with mean age range of 61-67 years, mean dose of $19-23 \mathrm{mg} / \mathrm{kg}$ and median duration of 14 days. ${ }^{6}$ In one study where the thrombocytopenia occurrence has been analysed based on presence or absence of renal insufficiency showed $57 \%$ and $33 \%$ with and without renal insufficiency with mean age of 68 years with dose of $600 \mathrm{mg}$ BD and mean duration of 10 days. ${ }^{14}$ 
Table 1: Characteristics of the studies.

\begin{tabular}{|c|c|c|c|c|c|c|c|c|c|c|}
\hline $\begin{array}{l}\text { Authors and } \\
\text { Place of } \\
\text { study }\end{array}$ & $\begin{array}{l}\text { Type of } \\
\text { study and } \\
\text { Sample } \\
\text { size (N) }\end{array}$ & $\begin{array}{l}\text { Thrombo- } \\
\text { cytopenia } \\
\text { (TP) } \\
\text { definition }\end{array}$ & $\begin{array}{l}\text { With/ } \\
\text { with- } \\
\text { out } \\
\text { TP }\end{array}$ & $\begin{array}{l}\text { Age } \\
\text { (mean) } \\
\text { years }\end{array}$ & $\begin{array}{l}\text { Number } \\
\text { of } \\
\text { subjects } \\
(\mathrm{N})\end{array}$ & $\begin{array}{l}\text { Dose of } \\
\text { linezolid } \\
(\text { Mean } \pm \text { SD) } \\
\text { mg/kg body } \\
\text { wt. }\end{array}$ & $\begin{array}{l}\text { Duration } \\
\text { of } \\
\text { linezolid } \\
\text { (Mean) } \\
\text { day/ } \\
\text { week }\end{array}$ & $\begin{array}{l}\text { Occurrence } \\
\text { (percentage) }\end{array}$ & $\begin{array}{l}\text { Baseline } \\
\text { platelet } \\
\text { count } \\
\left(10^{3} /\right. \\
\left.\mathbf{m m}^{3}\right)\end{array}$ & $\begin{array}{l}\mathrm{CrCl} \\
(\mathrm{ml} / \\
\mathrm{min})\end{array}$ \\
\hline \multirow{2}{*}{$\begin{array}{l}\text { Niwa.T et al }{ }^{1} \\
\text { Japan }\end{array}$} & \multirow{2}{*}{$\begin{array}{l}\text { Pros- } \\
\text { pective } \\
50\end{array}$} & \multirow{2}{*}{$\begin{array}{l}>25 \% \text { and } \\
<11 \mathrm{lakh} / \\
\mathrm{mm}^{3}\end{array}$} & $\begin{array}{l}\text { With } \\
\text { TP }\end{array}$ & 66 & 9 & $24.3 \pm 2.1$ & 12 days & $18 \%$ & $179 \pm 96$ & $\begin{array}{l}64.5 \pm \\
60.4 \\
\end{array}$ \\
\hline & & & $\begin{array}{l}\text { With- } \\
\text { out TP }\end{array}$ & 62 & 41 & $20.4 \pm 4.2$ & 12 days & & $274 \pm 143$ & $\begin{array}{l}103.6 \pm \\
89.0\end{array}$ \\
\hline \multirow{2}{*}{$\begin{array}{l}\text { Chen.C et } \\
\text { al }^{11} \\
\text { China }\end{array}$} & \multirow{2}{*}{$\begin{array}{l}\text { Retro- } \\
\text { spective } \\
254\end{array}$} & \multirow{2}{*}{$\begin{array}{l}>25 \% \\
\text { reduction } \\
\text { in baseline }\end{array}$} & $\begin{array}{l}\text { With } \\
\text { TP }\end{array}$ & 61.36 & 69 & $19.99 \pm 4.18$ & $\begin{array}{l}10.31 \pm \\
5.64 \text { days }\end{array}$ & $50 \%$ & $\begin{array}{l}212.5 \pm \\
76.96\end{array}$ & $\begin{array}{l}87.67 \pm \\
59\end{array}$ \\
\hline & & & $\begin{array}{l}\text { With- } \\
\text { out TP }\end{array}$ & 56.83 & 185 & $17.83 \pm 4.39$ & $\begin{array}{l}8.55 \pm 5.54 \\
\text { days }\end{array}$ & & $\begin{array}{l}224.71 \pm \\
72.85\end{array}$ & $\begin{array}{l}106.90 \\
\pm \\
58.28 \\
\end{array}$ \\
\hline \multirow{2}{*}{$\begin{array}{l}\text { Bi L.et al }{ }^{13} \\
\text { China }\end{array}$} & \multirow{2}{*}{$\begin{array}{l}\text { Retro- } \\
\text { spective } \\
50\end{array}$} & \multirow{2}{*}{$\begin{array}{l}>25 \% \text { and } \\
<11 \mathrm{lakh} / \\
\mathrm{mm}^{3}\end{array}$} & $\begin{array}{l}\text { With } \\
\text { TP }\end{array}$ & $83 \pm 9$ & 24 & $600 \mathrm{mg} \mathrm{BD} *$ & $14 \pm 2$ days & $48 \%$ & $\begin{array}{l}204 \pm \\
118\end{array}$ & $46 \pm 36$ \\
\hline & & & $\begin{array}{l}\text { With- } \\
\text { out TP }\end{array}$ & $80 \pm 11$ & 26 & $600 \mathrm{mg} \mathrm{BD} *$ & $12 \pm 2$ days & & $272 \pm 101$ & $60 \pm 43$ \\
\hline \multirow{2}{*}{$\begin{array}{l}\text { Garazzino } \mathrm{S} \\
\text { et } \mathrm{a}^{15} \\
\text { Italy }\end{array}$} & \multirow{2}{*}{$\begin{array}{l}\text { Pros- } \\
\text { pective } \\
31\end{array}$} & \multirow{2}{*}{$\begin{array}{l}>25 \% \\
\text { reduction } \\
\text { in baseline }\end{array}$} & $\begin{array}{l}\text { With } \\
\text { TP }\end{array}$ & 50.5 & 2 & $600 \mathrm{mg} \mathrm{BD} *$ & 12 weeks & $16.6 \%$ & 220 & \\
\hline & & & $\begin{array}{l}\text { With- } \\
\text { out } \\
\text { TP }\end{array}$ & & 29 & $600 \mathrm{mg} \mathrm{BD} *$ & & & & \\
\hline \multirow{2}{*}{$\begin{array}{l}\text { Natsumoto B } \\
\text { et al } \\
\text { Japan }\end{array}$} & \multirow{2}{*}{$\begin{array}{l}\text { Retro- } \\
\text { spective } \\
101\end{array}$} & \multirow{2}{*}{$\begin{array}{l}>50 \% \\
\text { reduction } \\
\text { in baseline }\end{array}$} & $\begin{array}{l}\text { With } \\
\text { TP }\end{array}$ & 67.83 & 42 & $23.47 \pm 5.1$ & $\begin{array}{l}\text { 14(3-67) } \\
\text { days** }\end{array}$ & $48 \%$ & 289.98 & $\begin{array}{l}67.2 \pm \\
41.57\end{array}$ \\
\hline & & & $\begin{array}{l}\text { With- } \\
\text { out TP }\end{array}$ & 61.76 & 59 & $19.9 \pm 5.3$ & $\begin{array}{l}14(1-63) \\
\text { days } * *\end{array}$ & & 249.63 & $\begin{array}{l}181.85 \\
\pm \\
156.9 \\
\end{array}$ \\
\hline \multirow{2}{*}{$\begin{array}{l}\text { Hanai Y et } \\
\mathrm{al}^{7} \text { Japan }\end{array}$} & \multirow{2}{*}{$\begin{array}{l}\text { Retro- } \\
\text { spective } \\
221\end{array}$} & \multirow{2}{*}{$\begin{array}{l}>30 \% \\
\text { reduction } \\
\text { in baseline }\end{array}$} & $\begin{array}{l}\text { With } \\
\text { TP }\end{array}$ & $\begin{array}{l}67.6 \pm \\
13.1 \\
\end{array}$ & 107 & $21.8 \pm 2.4$ & $\begin{array}{l}16.0 \pm \\
13.6 \text { days }\end{array}$ & $48.4 \%$ & $\begin{array}{l}239.8 \pm \\
133.2\end{array}$ & $\begin{array}{l}35 \pm \\
24.3\end{array}$ \\
\hline & & & $\begin{array}{l}\text { With- } \\
\text { out TP }\end{array}$ & $\begin{array}{l}61.7 \pm \\
15.2\end{array}$ & 114 & $21.0 \pm 2.3$ & $\begin{array}{l}11.6 \pm \\
6.9 \text { days }\end{array}$ & & $\begin{array}{l}239.0 \pm \\
140.0\end{array}$ & $\begin{array}{l}78.4 \pm \\
36.4\end{array}$ \\
\hline $\begin{array}{l}\text { Wu H et al }{ }^{14} \\
\text { Taiwan }\end{array}$ & $\begin{array}{l}\text { Pros- } \\
\text { pective } \\
13\end{array}$ & $\begin{array}{l}>25 \% \\
\text { reduction } \\
\text { in baseline }\end{array}$ & $\begin{array}{l}\text { With } \\
\text { TP }\end{array}$ & $\begin{array}{l}68.3 \pm \\
15.0\end{array}$ & 6 & $600 \mathrm{mg} \mathrm{BD} *$ & $\begin{array}{l}10.9 \pm \\
5.1 \text { days }\end{array}$ & $\begin{array}{l}33 \% \text { in } \\
\text { normal renal } \\
\text { function } \\
57 \% \text { in renal } \\
\text { pts }\end{array}$ & $\begin{array}{l}335.6 \pm \\
147.4\end{array}$ & $\begin{array}{l}\text { Not } \\
\text { given }\end{array}$ \\
\hline
\end{tabular}

TP-thrombocytopenia

*Standard dose was administered; ** Median duration of linezolid was documented instead of mean

Table 2: Characteristics of risk factors in this study.

\begin{tabular}{|c|c|c|c|c|c|c|c|c|c|}
\hline Studies & $\begin{array}{l}\text { Baseline } \\
\text { platelet } \\
\text { count } \\
\left(<200^{*} 10^{3} /\right. \\
\left.\mathbf{m m}^{3}\right)\end{array}$ & $\begin{array}{l}\text { Creatini } \\
\text { ne } \\
\text { clearance } \\
\text { (ml/min) }\end{array}$ & $\begin{array}{l}\text { Hemo- } \\
\text { dialysis }\end{array}$ & $\begin{array}{l}\text { Dose } \\
\text { mg/kg }\end{array}$ & $\begin{array}{l}\text { Body } \\
\text { weight } \\
\text { (<55kg) }\end{array}$ & $\begin{array}{l}\text { Duration } \\
\text { (days) }\end{array}$ & $\begin{array}{l}\text { Serum } \\
\text { albumin } \\
\text { (g/l) }\end{array}$ & $\begin{array}{l}\text { Caspo- } \\
\text { fungin }\end{array}$ & $\begin{array}{l}\text { Serum } \\
\text { creatinine } \\
\text { (mg/dl) }\end{array}$ \\
\hline $\begin{array}{l}\text { Niwa T } \\
\text { et al }^{1}\end{array}$ & $\begin{array}{l}\text { OR - } 24.9 \\
p-0.024\end{array}$ & & & $\begin{array}{l}>22 \\
O-9.55 \\
p-0.010\end{array}$ & $\begin{array}{l}\text { OR }-33.2 \\
p-0.012\end{array}$ & & & & \\
\hline $\begin{array}{l}\text { Chen C } \\
\text { et al }^{11}\end{array}$ & NA & $\begin{array}{l}\text { OR }-0.10 \\
p-0.04\end{array}$ & & $\begin{array}{l}>18 \\
\text { OR }-1.12 \\
p-0.001\end{array}$ & & NA & $\begin{array}{l}\text { OR }-0.95 \\
p-0.03\end{array}$ & $\begin{array}{l}\text { OR }-2.81 \\
p-0.01\end{array}$ & \\
\hline $\begin{array}{l}\text { Natsum } \\
\text { ato B et } \\
\text { al }^{6}\end{array}$ & & & & $\begin{array}{l}>20 \\
\text { Adjusted } \\
\text { OR - } 1.14 \\
\text { p- } 0.0026\end{array}$ & & & & & $\begin{array}{l}\text { Adjusted } \\
\text { OR - } 1.51 \\
p-0.04\end{array}$ \\
\hline $\begin{array}{l}\text { Hanai } \\
\text { Y et } \mathrm{al}^{7}\end{array}$ & & $\begin{array}{l}\text { Crcl }-52.2 \\
\text { Adjusted } \\
\text { OR - } 0.94 \\
\text { p- } 0.001\end{array}$ & $\begin{array}{l}\text { Adjusted } \\
\text { OR - } 3.32 \\
\text { p - } 0.011\end{array}$ & & & $\begin{array}{l}\text { 14.7 days } \\
\text { Adjusted } \\
\text { OR }-1.14 \\
\text { p - } 0.001\end{array}$ & & & \\
\hline
\end{tabular}

OR - odd's ratio; NA- Not available; $\mathrm{p}$ - $\mathrm{p}$ value 
Among seven studies, only four have evaluated risk factors for linezolid induced thrombocytopenia (Table 2), in one study by Natsumoto et al, serum creatinine and Dose Per $\mathrm{Kg}$ bodyweight per Day (DPKD, mg/kg/day) has been identified as risk factor. ${ }^{1,6,7,11}$ The adjusted odds ratio with $95 \%$ confidence interval for serum creatinine $(\mathrm{mg} / \mathrm{dl})$ and DPKD, were 1.51 (1.01-2.50) and 1.14 (1.05-1.26) respectively by $\mathrm{Bi}$ and multivariate logistic regression.

In a study conducted by Hanai $\mathrm{Y}$ et al, multiple logistic regression analysis identified creatinine clearance $(\mathrm{CrCl})$, hemodialysis and duration of linezolid therapy with adjusted odds ratio (OR) of $0.94(0.92-0.95, \mathrm{p}<0.001)$, $3.32(1.14-9.67, \mathrm{p}<0.011)$ and $1.14(1.07-1.21, \mathrm{p}<0.001)$ respectively with $95 \% \mathrm{CI}$ as the risk factors for linezolid induced thrombocytopenia. It was found that the incidence of thrombocytopenia was less $(9.1 \%)$ in normal subjects compared to renal insufficiency subjects $(18.5-81.4 \%)$, the discontinuation rate was higher in renal insufficiency compared $(7.4 \%-62.5 \%)$ to normal subjects $(2.3 \%)$ and the onset of thrombocytopenia ranging from 7-12 days. ${ }^{7}$ It was also observed that the incidence of anaemia was 8.6 $43.5 \%$ with linezolid duration ranged from 7-10 days and there was no discontinuation of the therapy due to anaemia.

Study by Niwa et al, depicts daily dose $>22 \mathrm{mg} / \mathrm{kg}$ and body weight $<55 \mathrm{~kg}$ with odds ratio (OR) of 9.55 with 95\% CI $(1.72-53.1, \mathrm{p}<0.010)$ and baseline platelet count of $<20 * 103 / \mathrm{mm}^{3}$ with OR of $6.20(1.30-29.5, \mathrm{p}<0.022)$ respectively as risk factors by univariate logistic regression and they also observed that dose adjustment of linezolid with one of the risk factor had prolonged onset of thrombocytopenia without affecting efficacy. ${ }^{1}$ The occurrence of thrombocytopenia increased from $18-72 \%$ when the DPKD and body weight of the patients increased from $<17$ to $>27 \mathrm{mg} / \mathrm{kg}$ and $>70 \mathrm{~kg}$ to $<45 \mathrm{~kg}$ respectively.

In retrospective cross-sectional Chen c et al study, creatinine clearance (OR-0.99), serum albumin concentration, daily dosage and caspofungin therapy were the risk factors by using multivariate logistic regression analysis and ROC curves. ${ }^{11}$

Few studies have reported that the mean area under the blood concentration time curve (AUC) of linezolid is high in $>80 \mathrm{yr}$ old patient and bodyweight $<40 \mathrm{~kg}$ (811.3 $\mu \mathrm{ghr} / \mathrm{ml})$ when compared to $<80 \mathrm{yr}$ and bodyweight $>40 \mathrm{~kg}(217.6 \mu \mathrm{ghr} / \mathrm{ml}) .{ }^{10}$ Further prevalence was $63.6 \%$ in AUC $>800 \mu \mathrm{g}-\mathrm{hr} / \mathrm{ml}$ and $51.3 \%$ in $\mathrm{AUC}<800 \mu \mathrm{ghr} / \mathrm{ml}$. $^{6}$ Dong et al reported that high plasma concentration of linezolid is a risk factor. ${ }^{11}$ Very limited studies were available, so further studies should be conducted to evaluate the risk factors associated with linezolid induced thrombocytopenia with respect to drug-drug interactions with linezolid and association between the linezolid plasma concentration and occurrence of thrombocytopenia.
The strength of the study was inclusion of both prospective and retrospective studies in-terms of evidence, gives good results and less bias. Study was unique in terms of the attempts made to draw some conclusion and evidence on the occurrence and the factors associated with it. Unfortunately, it was not possible to perform metaanalysis because of high level of heterogeneity $\left(\mathrm{I}^{2}-48 \%\right)$ among the selected articles.

The limitations of the study were; power of the study was not mentioned in any of the articles, only English language articles were included, the definition of thrombocytopenia was different in each article \& lastly, a limited number of studies were available for the review.

\section{CONCLUSION}

The occurrence of linezolid induced thrombocytopenia ranged from $18-50 \%$ and the associated risk factors were low creatinine clearance, hemodialysis, body weight $<55 \mathrm{~kg}$, increase DPKD low baseline platelet count, increased serum creatinine, increased duration of linezolid therapy, serum albumin concentration and concomitant caspofungin therapy. Hence, adequate and frequent monitoring for blood counts is essential in patients on linezolid therapy.

\section{Funding: No funding sources \\ Conflict of interest: None declared \\ Ethical approval: Not required}

\section{REFERENCES}

1. Niwa T, Watanabe T, Suzuki A, Ohmori T, Tsuchiya M, Suzuki T et al. Reduction of linezolid-associated thrombocytopenia by the dose adjustment based on the risk factors such as basal platelet count and body weight. Diagnostic Microbiology and Infectious Disease. 2014;79(1):93-7.

2. Dryden MS. Linezolid pharmacokinetics and pharmacodynamics in clinical treatment. J Antim chemoth. 2011;66(4):7-15.

3. Miller M, Schimz K. Oxazolidinones: a novel class of antibiotics. Cellular and Molecular Life Sciences (CMLS). 1999;56(3-4):280-5.

4. Zahedi BA, Rahbar M, Yousefi M, Asgharzadeh M, Samadi KH. Linezolid: a promising option in the treatment of Gram-positives. J Ant Chemoth. 2016;72(2):354-64.

5. Gemmell C. Virulence factor expression by Grampositive cocci exposed to subinhibitory concentrations of linezolid. J Ant Chemoth. 2002;50(5):665-72.

6. Natsumoto B, Yokota K, Omata F, Furukawa K. Risk factors for linezolid-associated thrombocytopenia in adult patients. Infection. 2014;42(6):1007-12.

7. Hanai Y, Matsuo K, Ogawa M, Higashi A, Kimura I, Hirayama $S$, et al. A retrospective study of the risk factors for linezolid-induced thrombocytopenia and anemia. J Inf Chemoth. 2016;22(8):536-42. 
8. Sweetman S. Antibacterial. In: Sweetman S, Blake P, editors. Martindale.The complete drug reference. $36^{\text {th }}$ ed. London: Pharmaceutical Press; 2009:158-361.

9. MacDougall C. Protein synthesis inhibitors and miscellaneous antibacterial agents. In: brunton L, Dandan R, Knollman B, editors. Goodman and Gilman's. The pharmacological basis of therapeutics. $13^{\text {th }}$ ed. New york: Mc Graw Hill education; 2018:1049-1066.

10. Nukui Y, Hatakeyama S, Okamoto K, Yamamoto T, Hisaka A, Suzuki H, et al. High plasma linezolid concentration and impaired renal function affect development of linezolid-induced thrombocytopenia. J Ant Chemoth. 2013;68(9):2128-33.

11. Chen C, Guo D, Cao X, Cai Y, Xu Y, Zhu M, et al. Risk Factors for Thrombocytopenia in Adult Chinese Patients Receiving Linezolid Therapy. Current Therapeutic Research. 2012;73(6):195-206.

12. Loo A, Gerzenshtein L, Ison M. Antimicrobial DrugInduced Thrombocytopenia: A Review of the
Literature. Seminars in Thrombosis and Hemostasis. 2012;38(08):818-29.

13. Bi L, Zhou S. Thrombocytopenia in Elderly Patients Who Received Intravenous Linezolid Therapy. Int J Gerontol. 2014;8(1):46-7.

14. Wu H, Wen C, Jang Y, Chen H. DI-056 Linezolid induced thrombocytopenia in a patient with renal insufficiency: A case report and a retrospective case study. European J Hos Pharm. 2016;23(1):A142.2-43.

15. Garazzino S, De Rosa F, Bargiacchi O, Audagnotto S, Maiello A, Di Perri G. Haematological safety of longterm therapy with linezolid. Int $\mathbf{J}$ Antimi Agent. 2007;29(4):480-3.

Cite this article as: Radha A, Anuradha HV, Radhika K. Occurrence of linezolid induced thrombocytopenia and its association with the risk factors: a review article. Int J Basic Clin Pharmacol 2018;7:2483-7. 